\title{
Life history traits of Characidium pterostictum (Characiformes, Crenuchidae) along the longitudinal gradient of a Neotropical river in southern Brazil
}

\author{
Raquel C. Fitz' ', Cesar A. Rodenbusch', Renato B. Dala-Corte² \& Marco A. Azevedo' \\ 1. Setor de Ictiologia, Museu de Ciências Naturais, Fundação Zoobotânica do Rio Grande do Sul, Rua Dr. Salvador França, 1427, $90.690-000$ Porto Alegre, RS, Brazil. \\ (marco-azevedo@fzb.rs.gov.br) \\ 2. Programa de Pós-Graduação em Ecologia, Universidade Federal do Rio Grande do Sul, Av. Bento Gonçalves 9500, Caixa Postal 15007, $91501-970$ Porto Alegre, \\ RS, Brazil.
}

Received 8 December 2015.

Accepted 5 October 2016.

DOI: $10.1590 / 1678-4766 e 2017002$

\begin{abstract}
Life history traits of Characidium pterostictum Gomes, 1947 (Characiformes, Crenuchidae) from three different reaches of the upper Sinos river, southern Brazil, were described and comparatively analyzed according to the longitudinal gradient. For all reaches, results indicated a seasonal reproductive strategy with a higher intensity during warmer months of higher photoperiod (November to February). Only females were found in the upstream reach and they were more numerous than males in all the sampled reaches. Mean absolute fecundity ranged from 5,189 ( $\pm 2,131 \mathrm{SD})$ to 7,394 ( $\pm 3,807 \mathrm{SD}$ ), whereas mean relative fecundity (oocytes per mg of female total weight) ranged from 1.08 ( $\pm 0.40 \mathrm{SD}$ ) to 1.12 ( $\pm 0.29 \mathrm{SD}$ ). Oocyte development was characterized as synchronic in two groups, typical of total spawning. Longitudinal gradient comparison suggests that body size (standard length) of C. pterostictum individuals and sex ratio were the only characteristics that differed between sampled reaches. Larger individuals and thus females tended to be more frequently found in upstream reaches of the Sinos river, with a decrease in body size and in the proportional number of females towards downstream.
\end{abstract}

KEYWORDS: Fishes, reproductive period, size at first maturation, fecundity, body size.

RESUMO. Características da história de vida de Characidium pterostictum (Characiformes, Crenuchidae) ao longo do gradiente longitudinal de um rio Neotropical no sul do Brasil. As características de história de vida de Characidium pterostictum Gomes, 1947 (Characiformes, Crenuchidae) de três diferentes trechos do rio dos Sinos, no sul do Brasil, foram descritas e analisadas comparativamente, de acordo com o gradiente longitudinal. Os resultados mostraram que, nos três trechos avaliados, a espécie possui período reprodutivo sazonalmente definido, com o pico de reprodução situado nos meses mais quentes e com maior comprimento do dia (novembro a fevereiro). O número de fêmeas foi sempre superior ao de machos e, no ponto mais a montante, somente fêmeas foram encontradas. A fecundidade absoluta média estimada para a espécie variou entre $5.189( \pm 2.131 \mathrm{SD})$ e 7.394 ( $\pm 3.807 \mathrm{SD})$, enquanto que a fecundidade relativa média (oócitos por mg de peso total da fêmea) variou entre 1,08 ( $\pm 0,40 \mathrm{SD})$ e 1,12 ( $\pm 0,29 \mathrm{SD})$. O desenvolvimento oocitário foi do tipo sincrônico em dois grupos, típico de espécies que apresentam desova total. A comparação no gradiente longitudinal sugere que o tamanho corporal dos indivíduos de C. pterostictum (comprimento padrão) e a proporção sexual foram as únicas características que diferiram entre os trechos amostrados. Aparentemente, há uma tendência de indivíduos maiores e, portanto, de fêmeas serem mais frequentes em trechos mais a montante do rio dos Sinos, com um decréscimo no tamanho corporal e na proporção de fêmeas em relação aos machos de montante para jusante.

PALAVRAS-CHAVE: Peixes, período reprodutivo, tamanho de primeira maturação, fecundidade, tamanho corporal.

Neotropical freshwater fish fauna is one of the richest in the world, inhabiting diverse environments and showing different life history strategies (VAzZoLER, 1996; VARI \& MALABARBA, 1998; ReIS et al., 2003). The varied reproductive strategies presented by distinct fish groups is one of the most important and interesting aspects of the plasticity found in Neotropical fishes (AzEvedo, 2010). According to TAMaTe \& MaEKaWa (2000), fishes exhibit flexible life histories, with their strategies being largely determined by environmental conditions. In riverine ecosystems, the reproductive traits may vary even between populations of the same species, depending on the environmental characteristics of the different habitats (BECKER et al., 2008). Variations in temperature, photoperiod, rainfall, niche and food availability as well as hydrological disturbances are identified as the main factors that influence certain reproductive traits, acting distinctly according to reproductive strategy, physiological traits and phylogenetic heritage of species (WINEMILLER, 1989; Vazzoler \& Menezes, 1992; Braga et al., 2012; EsPírito-SANTO et al., 2013; RomÁn-P et al., 2014).

A major problem in studies on reproductive biology studies is to show how a reproductive strategy is adaptive to particular environmental circumstances and also to elucidate the causal mechanisms that produce the observed 
pattern (Mazzoni \& IgLesias-Rios, 2002). Although the importance of studies on reproduction has been recognized, the currently available data encompasses only a small number of Neotropical species, especially if considering the great diversity of the Neotropical region. Furthermore, the available information is fragmented and usually only addresses a few reproductive aspects of individuals, sampled in single site, making difficult to develop comparative studies on reproductive patterns and to elucidate the mechanisms driving their variations.

Life history strategies of freshwater fishes can be shaped by environmental factors, such as water level and oxygen, as well as by biotic factors, such as predation and competition. These factors that shape species life history strategy show the capacity of fish species to adapt in order to maintain populations in varied environmental conditions (LobÓN-Cerviá et al., 1991; Lobón-Cerviá et al., 1993; Leonardos \& Sinis, 1999; Menezes \& Caramaschi, 2000). Therefore, intra and interspecific variations in the life history traits may be related to patterns of spatial occupation, distribution and use of the different environments and segments of the rivers throughout the fish's life cycle (Menezes \& Caramaschi, 2000; Mazzoni et al., 2004; Braga et al., 2007). This may drive spatial segregation of populations even in the same aquatic environment (BRAGA et al., 2012).

Crenuchidae is a family of Characiformes that occurs in Neotropical freshwater environments, from Panama to Argentina, and includes around 70 species: 47 of belonging to the genus Characidium Reinhardt, 1867 (BUCKUP, 2003). Characidium pterostictum Gomes, 1947 - a South American darter representative - is a small-sized species (reaches eight centimeters long) with a wide distribution, occurring in the Uruguay river drainages as well as Brazilian coastal drainages, from São Paulo to Rio Grande do Sul states (BUCKUP, 2003; BuCKUP et al., 2007). The species is commonly found in stream sections of distinct environmental characteristics and widely distributed along the longitudinal position, inhabiting watercourses with varied width, depth, water velocity, temperature and food resources. BECKER et al. (2008) found variation in life history characteristics of two C. pterostictum populations inhabiting sites that supposedly differed regarding harshness of flash floods. Nevertheless, although this species is widely distributed and relatively abundant, its reproductive traits and variation are still seldom studied (BraGa, 2006).

In order to contribute for understanding variation in life history strategy of riverine fish species in Neotropical region we describe variation in the population structure and reproductive tactics of $C$. pterostictum sampled in different reaches of the upper Sinos river, southern Brazil. We compared populations sampled along the longitudinal gradient of the river regarding the following characteristics: body size, sex ratio, reproductive period and its relation to abiotic and biotic factors, size at first sexual maturity, absolute and relative fecundity and oocyte development and size. Our study aimed to demonstrate the degree of variation that small-sized riverine fishes can exhibit in their life history traits even between sites located relatively near to each other.

\section{MATERIAL AND METHODS}

Study area and fish sampling. Monthly samples were carried out from January to December 2007 at three sites in the upper Sinos river (upstream, intermediate and downstream sites), which is located in eastern Rio Grande do Sul, Brazil:

1) The upstream site (22J0569393 UTM6711519) is located at $\approx 240 \mathrm{~m}$ above sea level, $4.5 \mathrm{~km}$ from Sinos river headwaters, and corresponds to a $2^{\text {nd }}$ order segment (sensu STRAHLER, 1957). This site is characterized by shallow waters, usually ranging from less than one meter to as long as two meters wide in some areas. The river width ranges between five and nine meters, with predominance of riffles and steep slopes. Substrate consists of boulders and cobbles and margins present preserved riparian vegetation.

2) The intermediate site (22J0569391 UTM 6708705) is located at $\approx 170 \mathrm{~m}$ above sea level, $7.2 \mathrm{~km}$ from the headwaters, and corresponds to a $3^{\text {rd }}$ order segment. It has a moderate slope in the riffles, which are followed by a pool habitat. Site depth reaches around two meters and substrate is composed mainly by cobbles of various sizes plus sand. Channel width ranges between 10 and 17 meters. Compared to the upstream site, the riparian vegetation in the intermediate site is more sparse.

3) Downstream site (22J0555421 UTM6707164) is located at $\approx 22 \mathrm{~m}$ above sea level, $30 \mathrm{~km}$ from the headwaters, and corresponds to a $4^{\text {th }}$ order segment. There are several riffles (less than one meter deep) interspersed backwaters (more than two meters deep). The width ranges from 21 to 30 meters and the substrate is composed by mixed grain-sizes, including boulder, cobble, gravel and sandy/silty sediments.

Fish sampling effort in each site was standardized by using 20 times a dip net in the stream bottom to sample riffles and by applying three seine net hauls in deeper and slower waters. Immediately after the captures, specimens were fixed in $10 \%$ formalin and, posteriorly, transferred to $70 \%$ ethanol in the lab.

Reproductive traits and data analysis. To analyze the reproductive traits of $C$. pterostictum, measurements of standard length $(\mathrm{SL}, \mathrm{mm})$ and total weight $\left(\mathrm{W}^{\mathrm{T}}, \mathrm{g}\right)$ were taken. Specimens were then dissected under a stereomicroscope to recognition and determination of sex and maturation stages. Gonads were both examined macroscopically and under an optical microscopy, according to the scale of gonadal maturation stages proposed by BROWN-PETERSON et al. (2011), which classifies as "spawning capable" the phase that indicates the reproductive period. For the optical microscopy analysis, the gonads were dehydrated through an ascendant grade of ethanol, infiltrated and embedded in Glicolmetacrylate resin. Longitudinal sections ( $3 \mu \mathrm{m}$ thick) were obtained through glass blades, stained with PAS + ferric hematoxylin + Metanil Yellow (QuinteroHUNTER et al., 1991). Gonads $\left(\mathrm{W}^{\mathrm{G}}\right)$, stomach $\left(\mathrm{W}^{\mathrm{S}}\right)$ and liver $\left(\mathrm{W}^{\mathrm{L}}\right)$, were weighed to assess relative weight and degree 
of development of these organs. These data allowed us to calculate the gonadosomatic index (GSI), stomach repletion index (RI) and hepatosomatic index (HSI), in accordance with the following formulas: $\mathrm{GSI}=\left(\mathrm{W}^{\mathrm{G}} / \mathrm{W}^{\mathrm{T}}\right) \times 100, \mathrm{RI}=$ $\left(\mathrm{W}^{\mathrm{S}} / \mathrm{W}^{\mathrm{T}}\right) \times 100($ SANTOS, 1978$)$ and $\mathrm{HSI}=\left(\mathrm{W}^{\mathrm{L}} / \mathrm{T}^{\mathrm{W}}\right) \times 100$ (VAZzoler, 1996).

The reproductive period was described based on monthly variation in the mean values of GSI and in the relative frequency of individuals with gonads in the spawning capable (females) or extrusion capable (males) phase. In order to analyze the influence of feeding activity, accumulation of energy reserves and abiotic factors on reproduction period, we tested the Persons's correlation between the mean monthly GSI values of males and females by sample site and variation in RI, HSI, water temperature, air temperature, rainfall and photoperiod.

Differences in sex ratio regarding number of individuals of females and males (total, per site and monthly) were evaluated through chi-square test $\left(\chi^{2}\right)$. Size at first gonadal maturation $\left(\mathrm{L}_{50}\right)$, in which $50 \%$ of the population is considered mature, was estimated separately for females and males by performing a logistic regression, fitted with a generalized linear model in $\mathrm{R}$ statistical environment $(\mathrm{R}$ Core Team, 2016), following Roa et al. (1999). To allow comparison between gender we included in this analysis only the specimens collected in one sampled site (downstream site), because females and males were not captured in all the sampled sites.

To estimate oocyte produced in each breeding/ spawning event we calculated absolute fecundity by counting the yolk oocytes found in females in the spawning capable phase. Also, we estimated relative fecundity by calculating the number of yolk oocytes per milligram of body weight (ADEBISI, 1987). Absolute and relative fecundity were estimated for each sampling site. To infer the type of oocyte development, all oocytes were measured under a stereomicroscope with a scaled ocular and grouped by intervals of length classes (mm). This analysis was used to infer the spawning type (VAZzoLER, 1996).

Differences in the SL and GSI values between males and females and between sampling sites were evaluated with two-way analysis of variance (ANOVA). In these tests, SL and log-transformed GSI were the dependent variables predicted by the factors gender and sites. Differences in both absolute and relative fecundity of mature females as well as diameter of mature oocytes between sampled sites were tested with one-way ANOVA. Contrasts were posteriorly evaluated with Tukey's post test. Data met assumptions of normality and homogeneity of variance. All these analyzes were conducted in R statistical environment (R CORE TEAM, 2016).

\section{RESULTS}

A total of 278 specimens of C. pterostictum were collected in three sites. The highest number of individuals was found in the downstream site (176), totaling 76 males ranging from 28.1 to $53.1 \mathrm{~mm}$ (mean $42.7 \pm$ standard deviation 5.3 $\mathrm{mm} \mathrm{SL}$ ), and 100 females ranging from 29.5 to $79.4 \mathrm{~mm}$ $(51.3 \pm 13.0 \mathrm{~mm} \mathrm{SL})$. In the intermediate site, 77 specimens were recorded, being 13 males between 37.1 and $62.9 \mathrm{~mm}$ $(49.2 \pm 9.9 \mathrm{~mm} \mathrm{SL})$; and 64 females, ranging from 34.7 to $79.4 \mathrm{~mm}(55.6 \pm 10.3 \mathrm{~mm} \mathrm{SL})$. In the upstream site, we captured only 25 females, ranging from 39.4 to $73.9 \mathrm{~mm}$ $(63.9 \pm 9.33 \mathrm{~mm} \mathrm{SL})$.

Body size (SL) differed significantly between sites and between gender, as revealed by the two-way ANOVA $\left(\mathrm{F}=27.9 ; \mathrm{df}=3,222 ; \mathrm{P}_{\text {overall }}<0.001 ; \mathrm{P}_{\text {sites }}<0.001 ; \mathrm{P}_{\text {gender }}\right.$ $<0.001)$. Females tended to be larger than males, and individuals captured at upstream site were usually larger in comparison to intermediate and to downstream sites, as well as intermediate site had larger individuals compared to downstream site, though not all pairwise comparisons were significant (Fig. 1).

We observed significant differences in adult GSI values when testing against the factors gender and sites, but the two-way ANOVA was only significant for sites $(\mathrm{F}=$ $5.6 ; \mathrm{df}=3,177 ; \mathrm{P}_{\text {overall }}=0.001 ; \mathrm{P}_{\text {sites }}<0.001 ; \mathrm{P}_{\text {gender }}=0.908$; Fig. 2). There was a great overlap of GSI values between factors and pairwise comparisons differed significantly only for females of the intermediate site compared to females of the upstream $(\mathrm{P}=0.006)$ and to females of the downstream site $(\mathrm{P}=0.008)$ (Fig. 2).

Number of females was greater than of males testing both downstream and intermediate sites together $\left(\chi^{2}=5.6\right.$, $\mathrm{df}=1, \mathrm{P}=0.018)$. Sex ratio for downstream site was 1.4 females to each male. In this site, sex ratio was significantly different from 1:1, at total and in most of the months, except April, August, and September. For the intermediate site, total sex ratio was 4.9 females to each male, being significantly different from 1:1 at total, but not significant if compared each month individually (Tab. I). Only females were captured in the upstream site.

Highest mean GSI values occurred in January, November, and December, for both males and females, in all the three sampled sites (Figs 3-9). High mean GSI values were also recorded for downstream site in February, September, and October (Figs 6, 7). Immature individuals were absent from GSI analysis. Thus, some months lack GSI values due to the absence of mature individuals or even due to the lack of samples.

Spawning capable ovaries were characterized by the predominance of oocytes within tertiary vitellogenesis, sometimes with the presence of nuclei migration, among some pre-vitellogenic oocytes; Extrusion capable testes showed many spermatozoa in the lumen with few sperm cysts (Figs 10,11). Gonadal maturation stages corroborated GSI analysis, showing higher frequency of individuals classified as "spawning capable" during the months of highest GSI values, for all the sampled sites, though a few "spawning capable" individuals were also observed in moths of low GSI values (Figs 12-15). A total of 41 individuals, corresponding to $14.7 \%$, were classified as immature. Analyzing sites separately, the proportion of immature individuals was $4 \%$ 


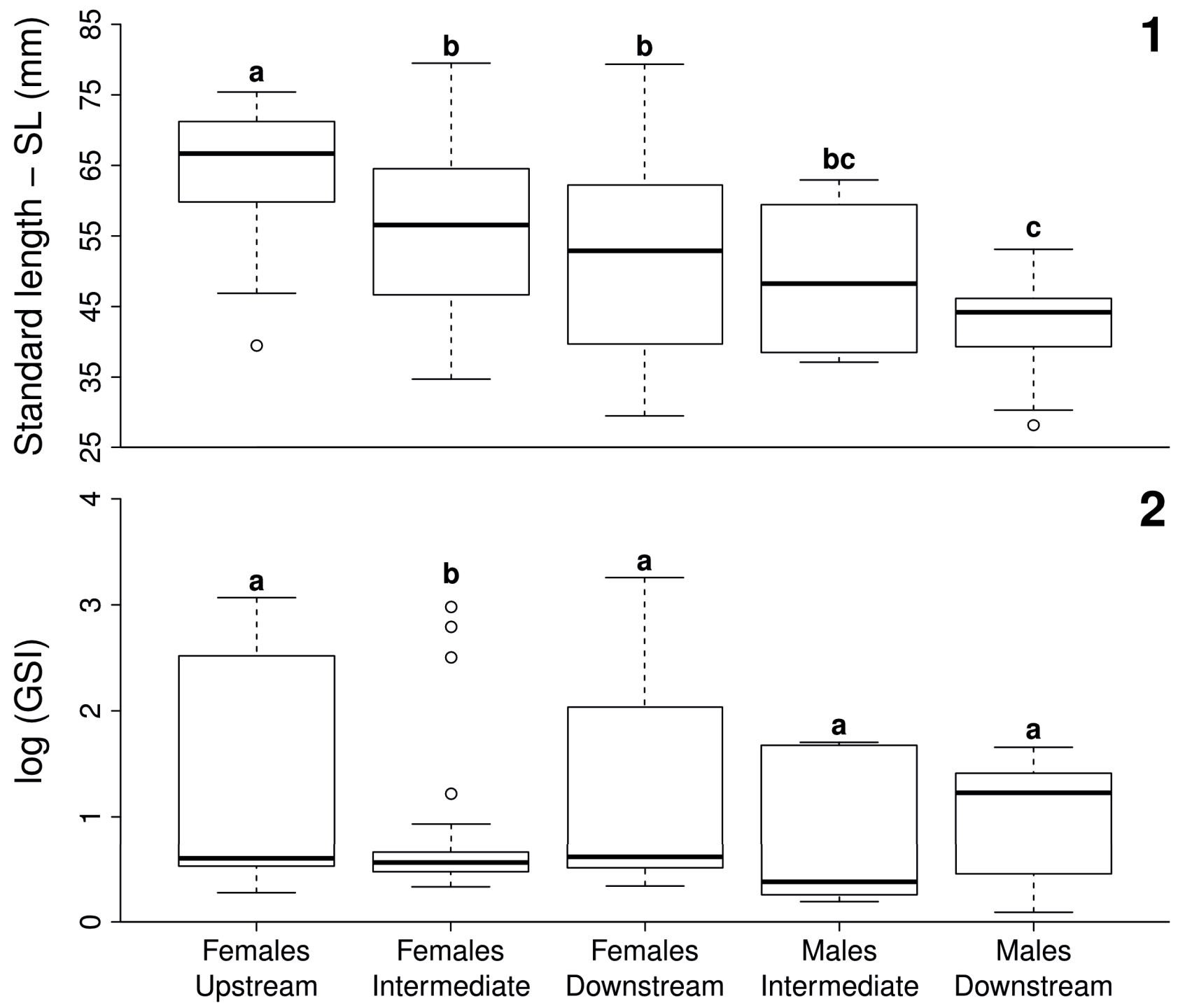

Figs 1, 2. Variation in standard length (SL, figure "1") and gonadosomatic index (GSI, figure "2") between adult females and males of Characidium pterostictum Gomes, 1947 sampled in the upstream, intermediate, and downstream sites, upper Sinos river, RS. Different letters highlight significant differences between contrasts $(\mathrm{P}<0.05)$. Boxplot shows median (central thicker line), first and third quartile (box limits), 95\% confidence interval of median (whiskers), and outliers.

Tab. I. Total and monthly differences between male and female number of individuals of Characidium pterostictum Gomes, 1947, sampled in the intermediate and downstream sites, upper Sinos river, RS, between January and December 2007. Only females were collected in upstream site. Values with an asterisk indicate significant differences in sex ratio, according to the chi-square test $\left(\chi^{2}\right)$.

\begin{tabular}{|c|c|c|c|c|c|c|}
\hline & \multicolumn{3}{|c|}{ Intermediate } & \multicolumn{3}{|c|}{ Downstream } \\
\hline & Males & Females & $\chi^{2}$ & Males & Femaless & $\chi^{2}$ \\
\hline January & 0 & 1 & & 10 & 6 & 1.00 \\
\hline February & 0 & 2 & & 3 & 5 & 0.50 \\
\hline March & 0 & 4 & & 1 & 2 & 0.33 \\
\hline April & 0 & 1 & & 6 & 6 & 0.00 \\
\hline May & 1 & 9 & $6.40^{*}$ & 2 & 6 & 1.00 \\
\hline June & 3 & 6 & 1.00 & 5 & 8 & 0.69 \\
\hline July & 1 & 11 & $8.33^{*}$ & 1 & 6 & 3.57 \\
\hline August & 0 & 1 & & 8 & 8 & 0.00 \\
\hline September & 0 & 3 & & 6 & 6 & 0.00 \\
\hline October & 0 & 1 & & 2 & 5 & 1.29 \\
\hline November & 2 & 9 & $4.45^{*}$ & 4 & 7 & 0.82 \\
\hline December & 6 & 16 & $4.55^{*}$ & 2 & 8 & 3.60 \\
\hline Total & 13 & 64 & $23.1 * *$ & 50 & 73 & $4.3^{*}$ \\
\hline
\end{tabular}




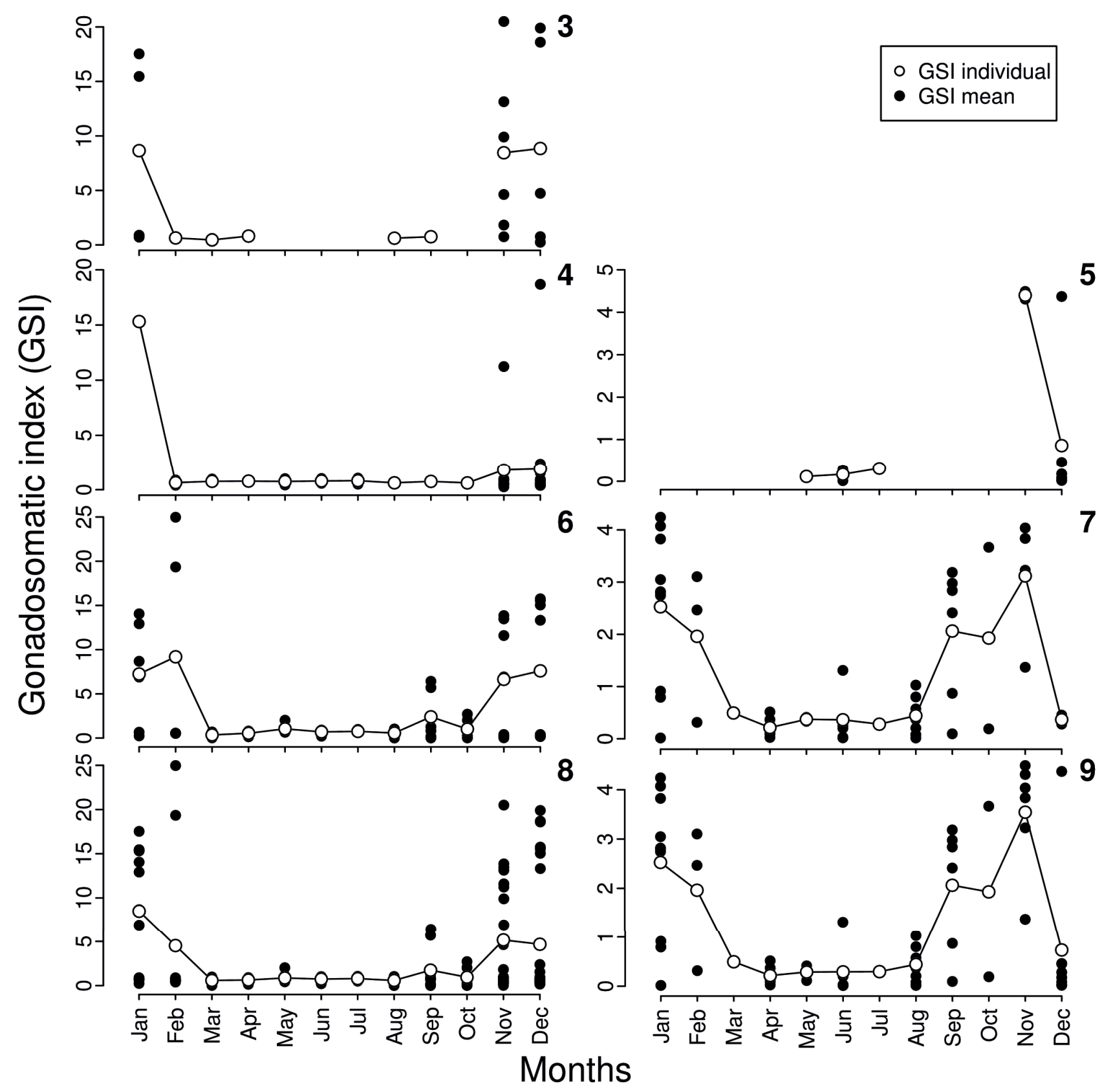

Figs 3-9. Individual values and mean monthly gonadosomatic index (GSI) of females and males of Characidium pterostictum Gomes, 1947 collected in upstream ( $3=$ females), intermediate $(4=$ females, $5=$ males $)$ and downstream sites $(6=$ females, $7=$ males $)$, from Sinos river, RS, between January and December 2007. Figures "8" and "9" correspond, respectively, to GSI of the total males and females sampled in all sites. Calculation of GSI values included only adults.

for the upstream site, $9 \%$ for the intermediate site, and $19 \%$ for the downstream site.

Monthly variation in the RI and HSI showed no clear pattern of seasonal variation. Only males from the intermediate site showed a significant positive correlation between GSI and HSI (Tab. II). Also, mean GSI and photoperiod were significantly and positively correlated for both females and males sampled in the downstream site (Tab. II).

The mean size at first sexual maturity $\left(\mathrm{L}_{50}\right)$ for females was $38.2 \mathrm{~mm}$ (SE $1.36 \mathrm{~mm}$ ) and for males was $40.2 \mathrm{~mm}$ (SE $0.84 \mathrm{~mm}$ ) (Figs 16, 17). Size (SL) of mature individuals at intermediate site ranged from 57.7 to $60.9 \mathrm{~mm}$ for males and from 58.5 to $79.5 \mathrm{~mm}$ for females. At the upstream site, where only females were captured; mature females ranged from 64.92 to $75.40 \mathrm{~mm}$ SL.

The mean absolute fecundity taking into account only the mature oocytes was $7394 \pm 3807$ for the upstream site, $8137 \pm 3844$ for the intermediate site, and $5189 \pm 2,131$ for the downstream site. The mean relative fecundity was 1.08 \pm 0.40 for the upstream site, $1.09 \pm 0.35$ for the intermediate site, and $1.12 \pm 0.29$ for the downstream site. There was no significant differences between sites for absolute fecundity ( $F$ 


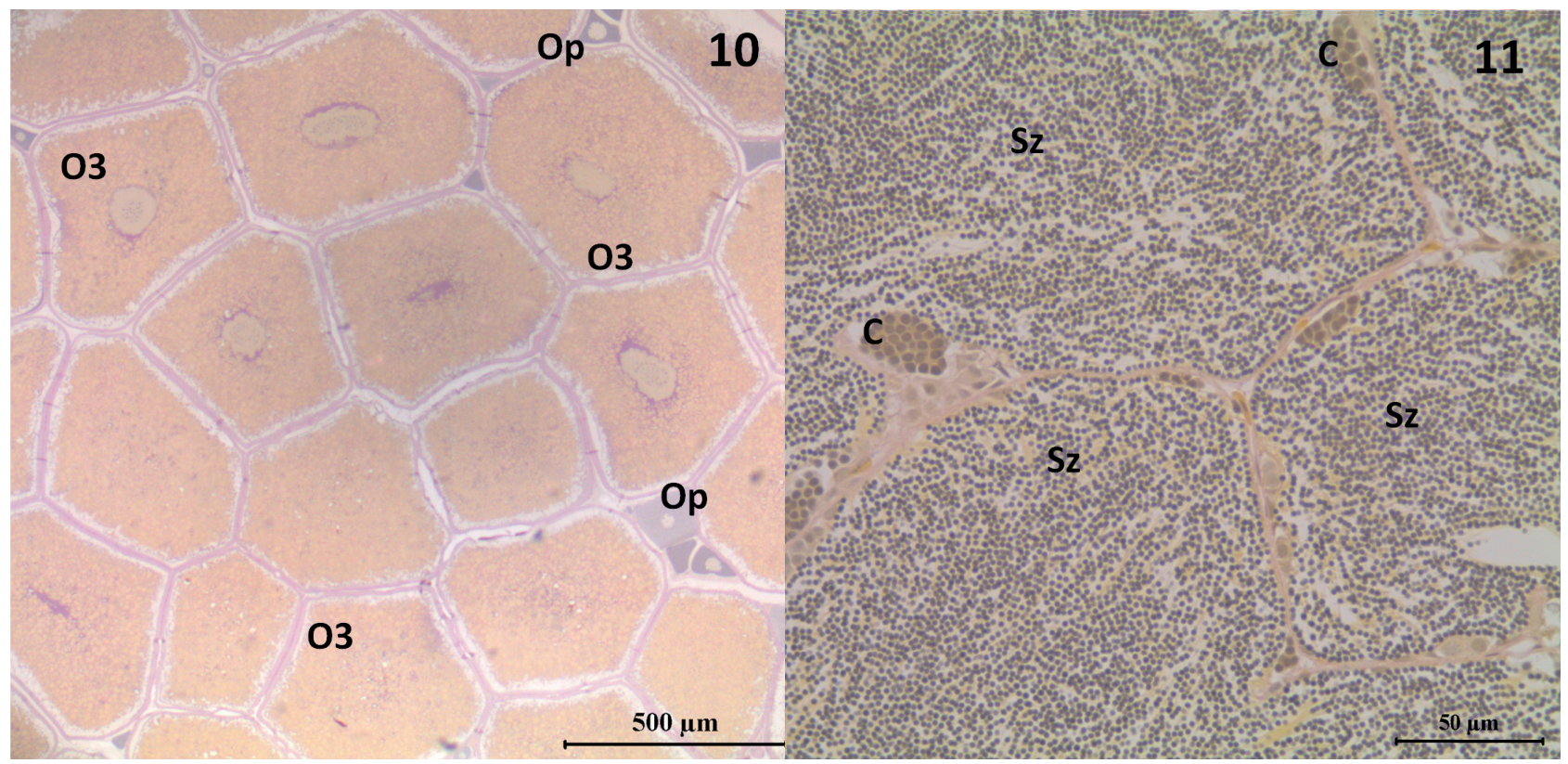

Figs 10, 11. Histological sections of gonads of Characidium pterostictum Gomes, 1947 specimens collected in upper Sinos river, RS, between January and December 2007 (3 $\mu \mathrm{m}$ thick sections, staining through PAS + ferric hematoxylin + Metanil Yellow). Figure "9" = spawning capable ovary, with predominance of tertiary yolky oocytes $(\mathrm{O} 3)$ among some pre-vitellogenic oocytes $(\mathrm{Op})$. Figure "10" = spawning capable testes showing many spermatozoa $(\mathrm{Sz})$ in the lumen and few sperm cysts $(\mathrm{C})$.

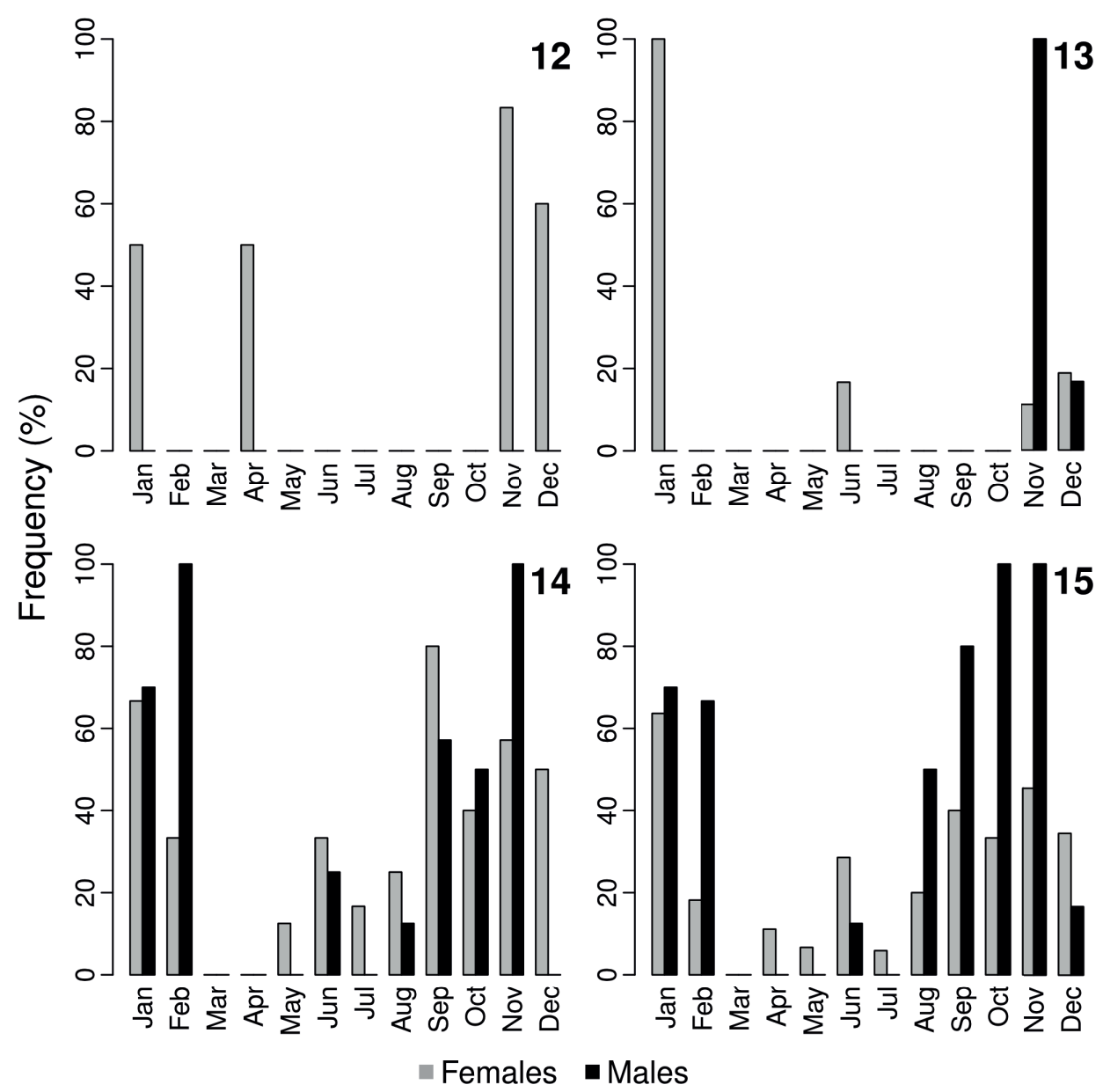

Figs 12-15. Relative frequency of females and males of Characidium pterostictum Gomes, 1947 with gonads in the spawning capable / extrusion phase sampled in the upstream (figure "12"), intermediate (figure "13") and downstream (figure "14") sites, upper Sinos river, RS between January and December 2007. Figure "15" corresponds to samples of all sites. 
Tab. II. Pearsons's correlations ( $r$ ) of mean gonadosomatic index (GSI) with biotic (RI and HSI) and abiotic factors (Twater, Tair, Photo and Rainfall) for females and males Characidium pterostictum Gomes, 1947 sampled at Upstream, Intermediate, and Downstream sites, upper Sinos river, RS. Values with asterisk indicate statistically significant correlation with Bonferroni correction P-value for multiple tests (corrected-P). Only females were sampled in the upstream site (RI, repletion index; HSI, hepatosomatic index; Twater, water temperature; Tair, air temperature; Photo, photoperiod; Rainfall, accumulated rainfall for the region).

\begin{tabular}{|c|c|c|c|c|c|c|c|}
\hline & Pearsons's correlation & RI & HSI & Twater & Tair & Photo & Rainfall \\
\hline \multirow{2}{*}{ Females Upstream } & $r$ & 0.09 & -0.55 & 0.38 & 0.37 & 0.80 & -0.46 \\
\hline & corrected-P & 1.000 & 1.000 & 1.000 & 1.000 & 0.353 & 1.000 \\
\hline \multirow{2}{*}{ Females Intermediate } & $r$ & -0.43 & -0.31 & 0.38 & 0.41 & 0.43 & -0.41 \\
\hline & corrected-P & 1.000 & 1.000 & 1.000 & 1.000 & 1.000 & 1.000 \\
\hline \multirow{2}{*}{ Females Downstream } & $r$ & -0.52 & -0.36 & 0.67 & 0.59 & 0.85 & -0.10 \\
\hline & corrected-P & 1.000 & 1.000 & 0.360 & 0.934 & $0.010 *$ & 1.000 \\
\hline \multirow{2}{*}{ Males Intermediate } & $r$ & 0.34 & -1.00 & 0.82 & 0.76 & 0.89 & -0.41 \\
\hline & corrected-P & 1.000 & $0.010 *$ & 1.000 & 1.000 & 1.000 & 1.000 \\
\hline \multirow{2}{*}{ Males Downstream } & $r$ & 0.25 & 0.68 & 0.59 & 0.59 & 0.90 & -0.18 \\
\hline & corrected-P & 1.000 & 0.421 & 1.000 & 1.000 & $0.004 *$ & 1.000 \\
\hline
\end{tabular}

$=1.23 ; \mathrm{df}=2,15 ; \mathrm{P}=0.320)$, neither for relative fecundity $(\mathrm{F}=0.03 ; \mathrm{df}=2,15 ; \mathrm{P}=0.971)$. Diameter of mature oocytes ranged from 0.60 to $0.85 \mathrm{~mm}$, taking into account all the sampled sites. Diameter of mature oocytes did not show significant differences between sites $(\mathrm{F}=2.1 ; \mathrm{df}=1,1251$; $\mathrm{P}=0.143$ ). Frequency of oocytes by diameter classes for the total sample indicated a synchronic oocyte development in two batches, typical of total spawning (Figs 18-21).

\section{DISCUSSION}

We found that reproductive traits presented by C. pterostictum in the upper Sinos river were relatively consistent when the three sampled sites are compared. Although some variance between sites were observed, we did not find evidence of differences between sites in the reproductive period and its relation to abiotic and biotic factors, in the size at first sexual maturity and in the absolute and relative fecundity, as well as in the oocyte development and size. However, body size and sex ratio seems to vary according to the longitudinal position along the river, as we detected a tendency of larger individuals and more females occurring towards upstream.

Overall, the monthly variation of both GSI and relative frequency of gonadal maturation stages for males and females demonstrate that $C$.pterostictum has a well-defined seasonal reproductive period in the upper Sinos river, occurring between November and February (austral spring and summer). However, we found that a few mature specimens may be found in other months. Although reproductive period seems to start in August in the downstream site, the reproductive peak occurred in spring and summer for all sites. These results corroborate studies conducted for other Characidium species, as well as for most species of Characiformes for which data are available (VAZZOLER \& Menezes, 1992; Braga, 2006; Azevedo, 2010). Another study conducted in the Maquiné river, Rio Grande do Sul, involving other populations of C.pterostictum, also reported similar results regarding reproductive period (BECKER et al., 2008). When compared the three sampled sites in the upper Sinos river, the similar reproductive period indicates that the main factors affecting extent and timing of C. pterostictum

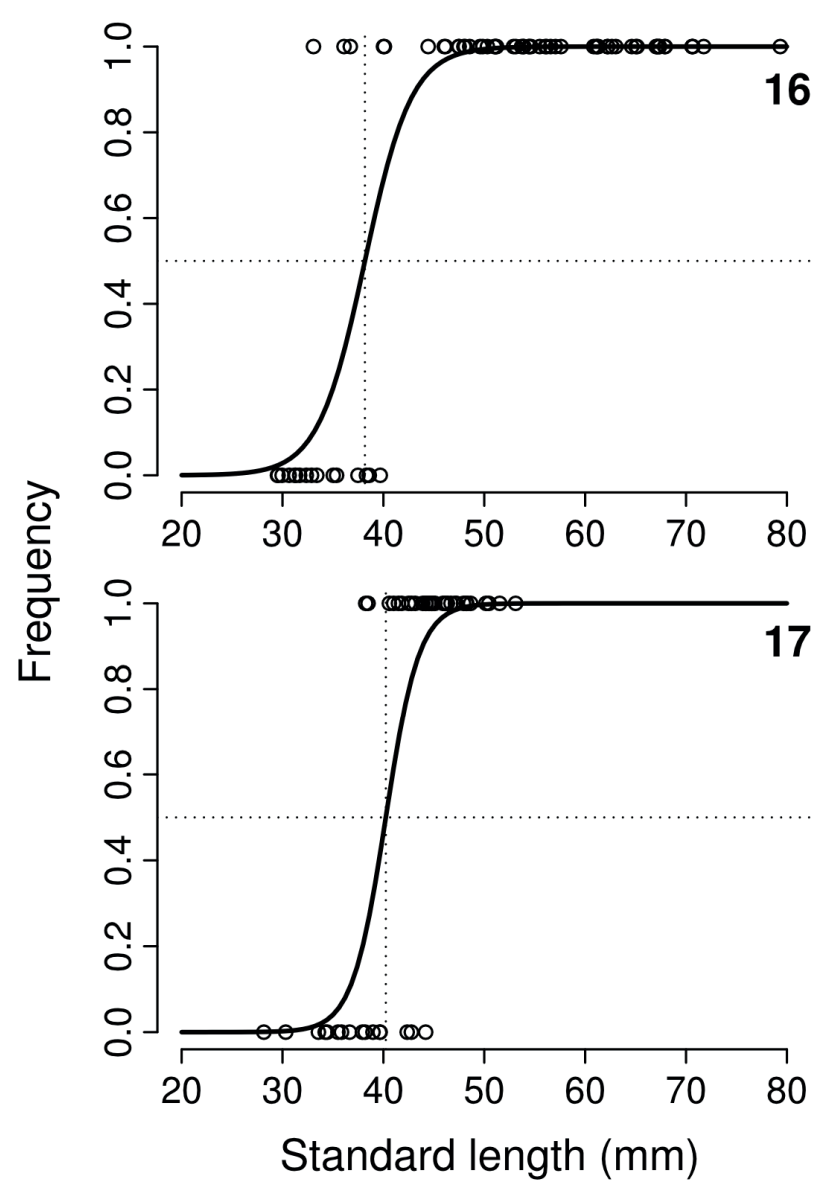

Figs 16, 17. Mean size at first sexual maturity $\left(\mathrm{L}_{50}\right)$ of females (figure "16") and males (figure "17") of Characidium pterostictum Gomes, 1947 from downstream site, upper Sinos river, RS, between January and December 2007.

breeding are not variable enough to cause divergence between populations in this trait.

According to Vazzoler \& Menezes (1992), a seasonal reproductive period for most Characiformes, notably in spring and summer in the southern hemisphere, is related to increases in temperature and photoperiod, which probably result in more favorable conditions to offspring development. Studies in temperate regions show a positive correlation between the change in water temperature and 


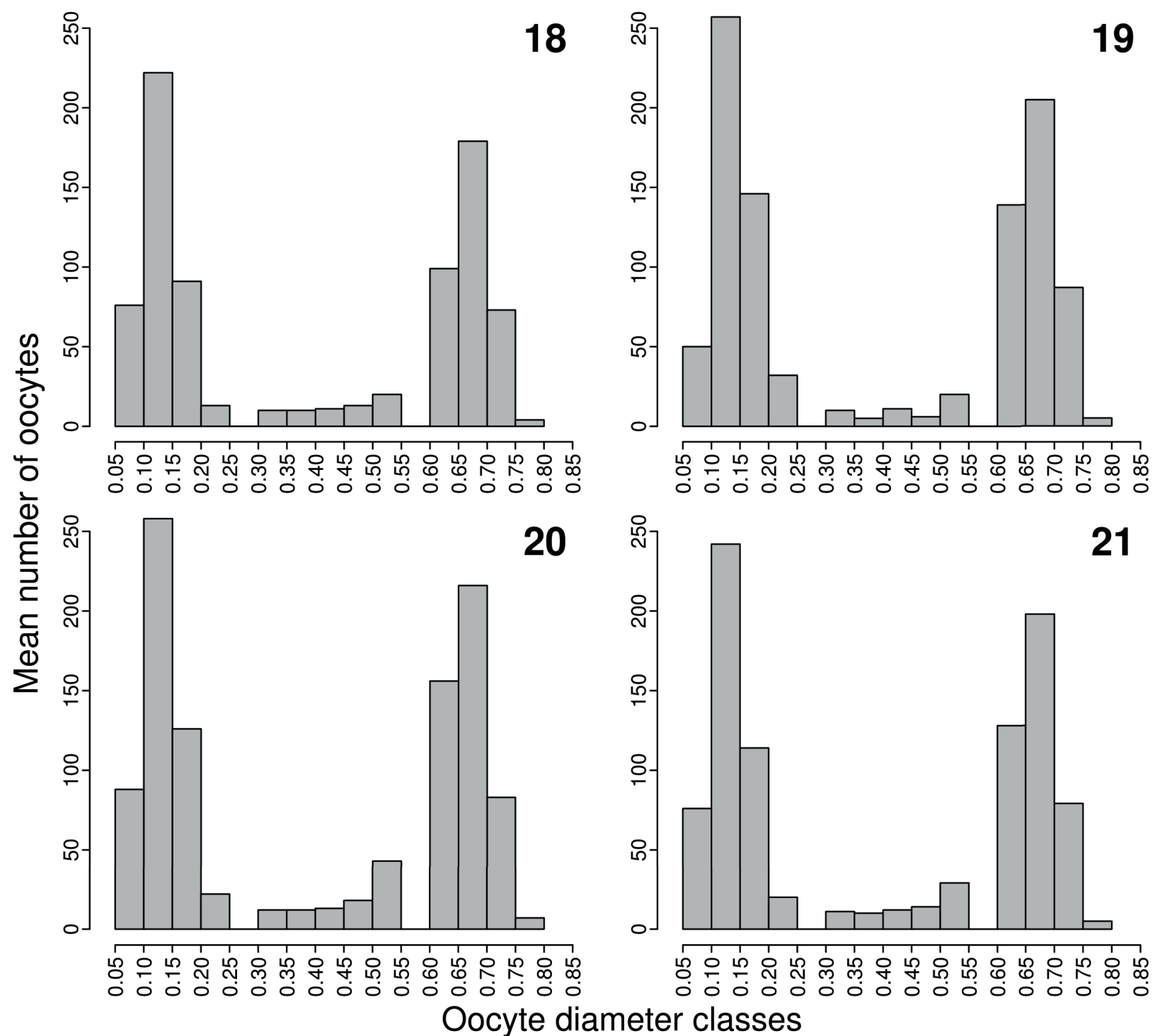

Figs 18-21. Mean frequency of oocytes by diameter class ( $\mathrm{mm}$ ) of mature gonads of female Characidium pterostictum Gomes, 1947 from upstream (figure "18"), intermediate (figure "19") and downstream (figure "20") sites in the upper Sinos river, RS. Figure "21" corresponds to the total individuals analyzed.

photoperiod with GSI for several teleost species (AzEVEDo et al., 2000; LAMPERT et al., 2007; AZEVEDO, 2010). In our study, a positive correlation between photoperiod and GSI was found only for the downstream site. Yet, the reproductive peak in warmer months with longer day length seems to indicate that photoperiod and temperature influence the onset of maturation in C. pterostictum in all the sampled sites. Therefore, the lack of differences between sites in the reproductive period may be explained because sites are subjected to similar conditions regarding the photoperiod.

The stomach repletion and hepatosomatic indices are usually related, respectively, to the intensity of food ingestion and to accumulation of energy reserves (RATTON et al., 2003; DE CARVAlHo et al., 2009; Veloso-JúNIOR et al., 2009). Studies have shown that some teleost fishes present higher values of RI and HSI before the reproductive period, accumulating energy that will be used for gonadal maturation, mating, spawning and parental care (VAZZOLER,
1996). Furthermore, the increase in gonadal volume during reproduction may reduce the stomach repletion capacity. Thus, it might be expected a negative correlation between these indices and GSI. However, our results did not clearly demonstrate a relationship between RI and HSI with GSI. At some sites, the RI and HSI are low in some months during reproduction, but low values are also found in other nonreproductive months. Hence, it was not possible to relate food consumption and energy accumulation to the proportional decrease in gonadal development. Other studies have also found absence of relationship between GSI with RI and HSI (e.g. LAMPERT et al., 2004; DALA-CoRTE \& AzEvedo, 2010). A possible explanation for this result is that food availability may be abundant throughout all the months of year for $C$. pterostictum in the studied sites. This hypothesis, however, lacks evidence and needs to be further tested.

We found that populations of $C$. pterostictum in the upper Sinos river had a greater number of females than 
males, and also that the ratio of females per male tended to increase towards upstream. In fact, only females were found in the upstream site. When analyzed the months separately, the absence of significant difference in sex ratio for the downstream site compared to the significant difference found for the intermediate site is explained by this pattern of the number of females increasing disproportionately towards upstream. Predominance in the number female individuals was also observed in populations of $C$. pterostictum from Maquiné river (BECKER et al., 2008). Literature usually relates the sex ratio differences to a differential behavior of individuals in the population during a life cycle event, which determines the predominance of individuals of one sex (VAZzoler, 1996). For example, differential mortality or growth rates biased to one sex may result in a greater number of individuals of the other sex. In addition to have proportionally a higher of individuals than males, we found that females also reach larger body size than males. Hence, we speculate that differential mortality and habitat suitability related to body size explain the bias of individual number towards females.

Characidium pterostictum is usually found in shallow, clear water and rocky bottom, being reported to prefer unshaded sites with moderate water flow (ARANHA et al., 1998; BozzetTI \& Schulz, 2004). However, streams are heterogeneous environments where physical and temporal variability, influence biotic patterns and processes, including life-history of fish (PoFf \& WARD 1990). BECKeR et al. (2008) identified the presence of a small-scale variability in the life history characteristics of C.pterostictum in different reaches of Maquiné river. In the upstream reach of this river, which is more susceptible to hydrological disturbance, the species seems to allocate more energy to growth (larger size, larger maturation size and higher condition factor) than to reproduction (lower GSI). According to these authors, although the species tends to be classified as opportunistic, local habitat characteristics may provide a more complex reproductive pattern, where different strategies for energy allocation and thus population persistence are favored. They also suggest that such plasticity is common in fish populations widely distributed in spatially variable habitats. Our results, however, corroborate only partially this hypothesis, as we found that body size and sex ratio were the only traits that differed between the three studied reaches of the upper Sinos river. In this sense, body size may be an important trait to explain variation in reproductive tactics adopted by populations in different environmental conditions spatially distributed along the longitudinal gradient.

The larger size of females compared to males found for the upper Sinos river may represent a strategy to increase the number of oocytes produced and therefore the number of offspring. This is the most common type of sexual dimorphism reported for fish, as larger size os females has been suggested to be an evolutionary advantage to produce more numerous and larger offspring (NIKOLSKY, 1963). A study with Characidium sp. in Ubatiba river, Southeastern Brazil, suggests that the observed pattern regarding the population size structure is determined by differences in reproductive strategy of males and females and that the absence of males in the larger length classes would be a consequence of their early maturation (MAZzoni et al., 2002). Our results, however, are not consistent with this hypothesis, as size at first maturity $\left(\mathrm{L}_{50}\right)$ of females and males were not different.

The mean absolute and relative fecundity found in our study were generally higher than those found for other Characidium species (MAZzoni et al., 2002, RoMANVALENCIA et al., 2006). Differing from these studies, however, we found a synchronous oocyte development in two groups, is typical of total spawning strategy, which means that the species spawns only once every reproductive season (VAZZOLER, 1996). High fertility rates associated with total spawning are generally related to species that have a high investment in a single reproductive event. MAzzoni et al. (2002) reported a Characidium species had the reproduction active all over the year, suggesting a continuous reproduction. ROMAN-VALENCIA et al. (2006) did not discuss the type of spawning for the studied Characidium species, but IGS seems to have multiple peaks and extended for a longer period (eight months, from September to May) compared to our results for C. pterostictum. Therefore, a higher fecundity found in present study can be associated to a shorter and concentrated reproductive period.

Results of the comparison between sample sites suggest there is no consistent variation in reproductive characteristics of the species among the studied sites. The studied Sinos river reaches are relatively distant from each other (more than $25 \mathrm{~km}$ between upstream and downstream sites along the drainage network) and vary considerably in terms of altitude (over $220 \mathrm{~m}$ between upstream and downstream) and geomorphological structure. Nevertheless, all three sites are located in the upper third of the Sinos river, less than $30 \mathrm{~km}$ from its headwaters. It is possible that the physical structural variability between these sites is not significant to the point of causing selective pressures that result in differences in the reproductive traits of $C$. pterostictum. We can not rule out, however, that the lack of significant differences in other reproductive traits between sites are influenced by the low number of sites evaluated ( $\mathrm{n}$ $=3$ ) and thus the low statistical power in detecting small effect sizes. In addition, populations further downstream may show greater difference in reproductive traits compared to the studied populations.

The body size (length) of individuals seems to be the only attribute that shows considerable variation between the sampled sites, along the longitudinal gradient, which was mainly associated to the sexual dimorphism of females reaching larger sizes than males. Apparently, there is a tendency for larger individuals to occupy the upper reaches of Sinos river. According to ABILHOA et al. (2011), during flash floods, eggs, larvae and small individuals along with rocks, branches and other aquatic fauna, are carried out to the lower portions of the stream. As they grow, they increase their swimming capability and become able to exploit habitats 
upstream, where they reproduce and complete their life's cycle. This dynamic ensure the long-term permanence of populations widely distributed along the drainage network. This hypothesis could explain the higher frequency of immature individuals in downstream site; the increase in individual body size from downstream to upstream; and considering that males reach smaller lengths than females, explaining the increasing predominance of females towards upstream reaches.

Acknowledgments. We thank to the staff of the Setor de Ictiologia of the Museu de Ciências Naturais of the Fundação Zoobotânica for their field and lab assistance; to the Dr. Vinicius Lampert, for his assistance with the manuscript translation and to the Dr. Felipe Zilio, for the help with statistical analyses. We are also grateful to CNPq (Conselho Nacional de Desenvolvimento Científico e Tecnológico) for the scholarship granted to the first author.

\section{REFERENCES}

Abilhoa, V.; Braga, R. R.; Bornatowski, H. \& Vitule, J. R. S. 2011. Fishes of the Atlantic Rain Forest Streams: Ecological Patterns and Conservation. In: Grillo, O. \& Venora, G. orgs. Changing Diversity in Changing Environment. Rijeka, Intech, p.259-282.

ADEBISI, A. A. 1987. The relationships between fecundities, gonadosomatics indices and egg sizes of some fishes of Ogun River, Nigeria. Archiv für Hydrobiologie 111:151-156.

Aranha, J. M.; Takeuti, D. F. \& Yoshimura, T. M. 1998. Habitat use and food partitioning of the fishes in a coastal stream of Atlantic Forest. Revista de Biologia Tropical 46:951-959.

AzEvEDO, M. A. 2010. Reproductive characteristics of characid fish species (Teleostei, Characiformes) and their relationship with body size and phylogeny. Iheringia, Série Zoologia 100(4):469-482.

Azevedo, M. A.; Malabarba, L. R. \& Fialho, C. B. 2000. Reproductive biology of the inseminated Glandulocaudine Diapoma speculiferum Cope (Actinopterygii: Characidae). Copeia 4:983-989.

Becker, F. G.; Carvalho, S. \& Hartz, S. M. 2008. Life-history of the South American darter, Characidium pterostictum (Crenuchidae): evidence for small scale spatial variation in a piedmont stream. Neotropical Ichthyology 6(4):591-598.

BozzetTi, M. \& Schulz, U. H. 2004. An index of biotic integrity based on fish assemblages for subtropical streams in southern Brazil. Hydrobiologia 529:133-144.

Braga, F. M. S. 2006. Aspectos da reprodução do gênero Characidium Reinhardt, 1867 (Crenuchidae, Caracidiinae) na microbacia do Ribeirão Grande, serra da Mantiqueira, sudeste do Brasil. Acta Scientiarum, Biological Sciences 28(4):365-371.

Braga, F. M. D. S.; Souza, U. P. \& Carmassi, A. L. 2007. Dinâmica populacional de Characidium lauroi e C. alipioi (Teleostei, Crenuchidae) na microbacia do Ribeirão Grande, serra da Mantiqueira Oriental, Estado de São Paulo. Acta Scientiarum, Biological Sciences 29(3):281-287.

Braga, R. R.; Braga, M. R. \& Vitule, J. R. S. 2012. Population structure and reproduction of Mimagoniates microlepis with a new hypothesis of ontogenetic migration: implications for stream fish conservation in the Neotropics. Environmental Biology of Fishes 96(1):21-31.

Brown-Peterson, N. J.; Wyanski, D.; Saborido-Rey, F.; Macewicz, B. J. \& Lowerre-BARBIERI, S. K. 2011. A Standardized Terminology for Describing Reproductive Development in Fishes. Marine and Coastal Fisheries 3(1):52-70.

Buckup, P. A. 2003. Family Crenuchidae. In: Reis, R. E.; Kullander S. O. \& Ferraris JR., C. J. eds. Check list of the freshwater fishes of South and Central America. Porto Alegre, Edipucrs. p.87-95.

Buckup, P. A.; Menezes, N. A. \& Ghazzi, M. S. 2007. Catálogo de espécies de peixes de água doce do Brasil. Rio de Janeiro, Museu Nacional. 195p.

Dala-Corte, R. \& Azevedo, M. A. 2010. Biologia reprodutiva de Astyanax henseli (Teleostei, Characidae) do curso superior do rio dos Sinos, RS, Brasil. Iheringia, Série Zoologia 100(3):259-266. de Carvalho, P. A.; Paschoalini, A. L.; Santos, G. B.; Rizzo, E. \& BAzzoli, N. 2009. Reproductive biology of Astyanax fasciatus (Pisces: Characiformes) in a reservoir in southeastern Brazil. Journal of Applied Ichthyology 25(3):306-313.

EsPírito-SANTO, H.; RodrígueZ, M. A. \& ZuANON, J. 2013. Reproductive strategies of Amazonian stream fishes and their fine scale use of habitat are ordered along a hydrological gradient. Freshwater Biology 58(12):2494-2504.

Lampert, V. R.; Azevedo, M. A. \& Fialho, C. B. 2004. Reproductive biology of Bryconamericus iheringii (Ostariophysi: Characidae) from rio Vacacaí, RS, Brazil. Neotropical Ichthyology 2(4):209-215.

Lampert, V. R.; Azevedo, M. A. \& Fialho, C. B. 2007. Reproductive Biology of Bryconamericus stramineus Eigenmann, 1908 (Ostariophysi: Characidae) from the Rio Ibicuí, RS, Brazil. Brazilian Archives of Biology and Technology 50(6):995-1004.

Leonardos, I. \& Sinis, A. 1999. Population age and sex structure of Aphanius fasciatus Nardo, 1827 (Pisces: Cyprinodontidae) in the Mesolongi and Etolikon lagoons (W. Greece). Fisheries Research 40(3):227-235.

Lobón-Cerviá, J.; Montańges, C. \& Sostoa, A. 1991. Influence of environment upon the life history of gudgeon, Gobio gobio (L.): a recent and successful colonizer of the Iberian Peninsula. Journal of Fish Biology 39(3):285-300.

Lobón-Cerviá, J.; Utrilla, C. G.; Querol, E. \& Puig, M. A. 1993. Population ecology of pike-cichlid, Crenicichla lepidota, in two streams of the Brazilian Pampa subject to a severe drought. Journal of Fish Biology 43(4):537-557.

Mazzoni, R.; Caramaschi, E. P. \& Fenerich-Verani, N. 2002. Reproductive biology of a Characidiinae (Osteichthyes, Characidae) from the Ubatiba river, Maricá-RJ. Brazilian Journal of Biology 62(3):487-494.

Mazzoni, R. \& Iglesias-Rios, R. 2002. Environmentally related life history variations in Geophagus brasiliensis. Journal of Fish Biology 61:1606-1618.

Mazzoni, R.; Schubart, S. A. \& Iglesias-Rios, R. 2004. Longitudinal segregation of Astyanax janeiroensis in Rio Ubatiba: a neotropical stream of south-east Brazil. Ecology of Freshwater Fish 13(3):231-234.

Menezes, M. S. \& Caramaschi, E. P. 2000. Longitudinal distribution of Hypostomus punctatus (Osteichthyes, Loricariidae) in a coastal stream from Rio de Janeiro, Southeastern Brazil. Brazilian Archives of Biology and Technology 43(2):221-227.

Nikolsky, G. V. 1963. The ecology of fishes. London, Academic Press. 352p.

Poff, N. \& WARD, J. 1990. Physical habitat template of lotic systems: Recovery in the context of historical pattern of spatiotemporal heterogeneity. Environmental Management 14(5):629-645.

Quintero-Hunter, I.; Grier, H. J. \& MusCato, M. 1991. Enhancement of histological detail using metanil yellow as counterstain in periodic acid/ Schiff's hematoxylin staining of glycol methacrylate tissue sections. Biotechnic \& Histochemistry 66(4):169-172.

Ratton, T. F.; Bazzoli, N. \& Santos, G. B. 2003. Reproductive biology of Apareiodon affinis (Pisces: Parodontidae) in the Furnas Reservoir, Minas Gerais, Brazil. Journal of Applied Ichthyology 19(6):387-390.

R CORE TEAM. 2016. R: A language environment for statistical computing. Vienna, Austria: R Foundation for Statistical Computing. Available at: http://www.rproject.org.

Reis, R. E.; Kullander, S. O. \& Ferraris Jr, C. J. 2003. Check list of the freshwater fishes of South and Central America. Porto Alegre, Edipucrs. 729p.

RoA, R.; ERnST, B. \& TAPIA, F. 1999. Estimation of size at sexual maturity: an evaluation of analytical and resampling procedures. Fishery Bulletin 97(3):570-580.

Román-P, C.; Román-Valencia, C. \& Taphorn, D. C. 2014. Trophic and reproductive ecology of a Neotropical characid fish Hemibrycon brevispini (Teleostei: Characiformes). Caldasia 36(2):289-304.

Roman-Valencia, C.; Hernandez, J. H. \& Samudio, H. F. 2006. Sobre ecologia de Characidium caucanum (Pisces: Crenuchidae) en el alto Rio Cauca, Colombia. Dahlia 9:33-42.

SAntos, E. P. 1978. Dinâmica de populações aplicada à pesca e piscicultura. São Paulo, HUCITEC/Editora da Universidade de São Paulo. 129p.

STRAHLER, H. N. 1957. Quantitative analysis of watershed geomorphology. Transactions of the American Geophysical Union 38(6):913-920. 
TAMATE, T. \& MAEKAWA, K. 2000. Interpopulation variation in reproductive traits of female masu salmon, Oncorhynchus masou. Oikos 90:209-218.

VARI, R. P. \& Malabarba, L. R. 1998. Neotropical Ichthyology: An Overview. In: Malabarba, L. R.; Reis, R. E.; Vari, R. P.; Lucena, Z. M. S. \& Lucena, C. A. S. eds. Phylogeny and Classification of Neotropical Fishes. Porto Alegre, Edipucrs, p.1-11.

VAZZOLER, A. E. A. M. 1996. Biologia da reprodução de peixes teleósteos: Teoria e prática. São Paulo, Eduem. 169p.

VAZzoler, A. E. A. M \& MenEZes, N. A. 1992. Síntese dos conhecimentos sobre o comportamento reprodutivo dos Characiformes da América do Sul (Teleostei, Ostariophysi). Revista Brasileira de Biologia 52(4):627-640.

Veloso-Júnior, V. C.; Guimarães-Cruz, R. J.; Barros, M. D. M.; Barata, R. S. L. \& SANTOS, J. E. 2009. Reproduction of the lambari Astyanax scabripinnis (Jenyns, 1842) (Pisces: Characidae) in a small stream in Southeastern Brazil. Journal of Applied Ichthyology 25(3):314-320. WinemilleR, K. O. 1989. Patterns of variation in life history among South American South American fishes in seasonal environments. Oecologia 81:225-241. 